Complete medical and dental care should involve both radio- and chemotherapy's early and late complications. Therefore, interdisciplinary care and consultations with leading physicians are necessary. Optimal control of side effects of oncological therapy can be obtained only by preliminary preparation of the patient's oral cavity preceding principal treatment, explaining him the importance of prophylactic activity and the necessity of taking care of oral hygiene rigorously. Precise clinical examination and taking a pantomogram enable the dentist to plan oral cavity sanitation. It is crucial as far as the dental treatment is concerned to eliminate all sources of possible injuries and infections. The dentist's purpose, if any pathology in the oral cavity appears, is to remove pain, prevent development of infections and facilitate the healing process.

Key words: chemotherapy, radiotherapy, oral cavity, side effects, treatment.

\section{Dental care of patients undergoing chemo- and radiotherapy}

\section{Anna Szyszkowska ${ }^{1}$, Marta Puławska ${ }^{1}$, Monika Lewicka², Joanna Koper ${ }^{1}$, Marta Malicka}

${ }^{1}$ The Department of Oral Surgery, Medical University of Lublin 2Department of Surgical Oncology, Medical University of Lublin

\section{Background}

Lesions in the oral cavity occurring in patients during oncological chemotherapy or radiotherapy constitute for them a serious health and emotional problem. Severe pain associated with the treatment significantly interferes with proper nutrition, speaking and use of prosthetic appliances. The severity of changes and their response to treatment often depend on the initial state of the oral cavity before the beginning of therapy. All untreated periodontal inflammation both marginal and apical, carious defects and lesions of the oral mucosa may predispose to rapid destruction of these tissues, longer treatment and worse prognosis. Successful treatment of local and systemic complications or minimizing their consequences are associated with an additional burden to the patient. Therefore, dental treatment and proper preparation of the oral cavity before oncological chemotherapy or radiotherapy should be implemented unconditionally to strive to reduce pain and unnecessary suffering of the patient.

\section{Side effects of chemotherapy}

Cytostatics are effective not only in rapidly dividing cancer cells, but also in normal cells of the body with a high mitotic index. These include the basal layer epithelial cells of the mucous membrane, influencing its rapid recovery. Damage to these cells results in atrophic changes in the epithelium of oral mucosa, which becomes thin and sensitive to chemical injury, and mechanical and thermal loads. In such a situation, numerous erythemas and ulcerations with a reduced tendency to heal are formed. Haematological toxicity of cytostatics causes leukopenia and neutropenia, resulting in an increased risk of infection, anaemia and thrombocytopenia associated with bleeding disorders. Acute inflammation of the lining of the mouth (mucositis) is a cause of major discomfort, and the formation of ulcerative changes covering large areas, especially of the oral mucosa lining, areas such as cheeks, upper and lower lip, the bottom of the mouth and the soft palate, and their superinfection by pathogenic microorganisms can become a gateway for infection of the whole body $[1,2]$. Loss of continuity of the lining of the oral mucosa, leucopenia, abnormal immune system (reducing the daily production of defence immunoprotein IgA and $\mathrm{gG}$ ) in patients undergoing chemotherapy and reduction of the defensive function of saliva as a result of xerostomia favour the development of an opportunistic infection or a systemic fungal infection, or systemic infection with bacteria from the oral cavity (sepsis) [1, 3]. Studies have shown that mucositis in these patients is not primarily of an inflammatory nature, and erosive changes are secondarily infected. Therefore, it is very important to prevent multiplication of germs in the mouth. Petechiae on the mucous membranes that express thrombocytopenia often occur when the platelet count falls below $50000 / \mathrm{mm}^{3}$ and are observed in areas exposed to trauma, mainly on the cheek mucosa in the line of occlusion and lower lip [4]. Pain due to the damage to the mucosa as well as taste and swallowing disorders associated with the antitumour therapy lead to malnutrition. 
Complications after chemotherapy may be early or late. Early complications appear approximately a week after cessation of medication and usually are manifested as erythematous inflammation of the oral cavity mucosa. Within a few weeks or months late complications occur in the form of ulceration and necrosis of the mucosa, periodontal inflammation, spontaneous bleeding, and candidiasis.

Among the cytotoxic agents the most adverse effect on the mucous membranes were observed during application of 5-fluorouracil, methotrexate, doxorubicin, melphalan, cytarabine, cyclophosphamide, Camptosar and bleomycin. The severity of the side effects is particularly marked in patients without sanitation of the oral cavity before cytostatic therapy [5].

\section{Side effects of radiotherapy}

The severity of changes is individually variable and depends not only on radiation dose and age, but also on the patient's genetic predispositions. Mucositis can be mild or severe, local or widespread. The most sensitive to radiation are cells undergoing keratosis, i.e. epithelium of red lips, buccal, soft palate and throat mucosa. Parotid gland serous cells are also very radiosensitive. Glandular tissue is replaced by loose fibrous connective tissue filled by lymphocytes and plasma cells [6]. As a consequence of degenerative changes the amount secreted by the salivary glands decreases to the value of $0.12-0.16 \mathrm{ml} / \mathrm{min}$ flow of saliva, which is the lower limit of risk of xerostomia [3]. Salivary buffering is also altered due to changes in the amount of electrolytes [6]. Dentin hypersensitivity within the irradiated field arises from the demineralization of enamel and saliva $\mathrm{pH}$ shift towards more acidic. Osteoradionecrosis - radiation necrotic osteitis - is a consequence of lack of capacity to compensate bone tissue vascular disorders, osteoblast deficits and alterations in tissue oxygenation. It occurs more frequently in patients with poor oral hygiene and untreated cavities, and periodontal disease and abandoned necrotic teeth predispose to its development $[6,7]$.

Side effects of therapy observed in different structures of the stomatognathic system may be more serious the younger the patient is and the higher are the doses of radiation and chemotherapeutic agents used. Noticeable local disorders in children are the effects of reduced intensity of facial skeleton growth and the insufficiency of the soft palate. Dental abnormalities such as hypodontia, microdontia, inhibition of development/root growth in length (rhizomicria, V-shaped roots), and delayed eruption of permanent teeth (dentitio tarda) are distant complications occurring in patients receiving irradiation in the area of the maxillary alveolar process or alveolar mandible during the development of tooth germs [8-10]. Occlusion irregularities ascertained in children treated with radiation of cancer in the head as a consequence of inhibiting growth of bone bases include the lack of space and crowding after symmetric radiotherapy and crossbite with an asymmetric open bite after asymmetric radiation caused by hypoplastic bone. Dental abnormalities appearing as complications of oncological treatment of young children are delayed eruption of permanent teeth as well as inhibition of the development of tooth buds, which may lead to hypodontia or shortening, or even total lack of roots of some teeth [10].

The development of acute radiation caries and periodontal inflammation described in both children and adults, which may be a consequence of direct exposure to drugs and/or radiation to the tissues of the teeth, as well as an indirect effect associated with reduced salivary flow, are early complications in the oral cavity [10]. Direct action of ionizing radiation leads to degenerative changes in the dental pulp disrupting its function; secondarily dentin structural changes occur as well as collagen degradation [11]. Enamel becomes brittle and more susceptible to cariogenic and mechanical factors [12]. Changes within the dentin are characterized by a decrease of hardness and yellowishbrown colour. Decay after irradiation grows rapidly, especially in children. It is located on the smooth surfaces of enamel, over a wide area of tooth crowns, causing pain during eating and drinking [11]. If the irradiated area includes masseter muscles, trismus may occur, which is possibly associated with muscle fibrosis. The impact of neurological disorders caused by underlying disease and treatment which lead to masseter muscle weakness (or unwilling, lazy chewing) and impede the self-cleaning of the mouth of debris should also be taken into account $[8,13]$. Astringent radiation lip scars, i.e. microstoma, cause narrowing of the mouth and problems with feeding and maintaining proper oral hygiene.

Dental problems of patients after irradiation of the head and neck can be sorted into three intervals. Early complications appear in the first two months after irradiation, and intermediate complications appear between two and twelve months after radiation. However, late complications develop not earlier than one year, or even many years after completion of radiotherapy [14].

\section{Classifications}

For many years classifications of complications related to oncological treatment have been developed. The World Health Organization (WHO) introduced a five-step scale for patients undergoing chemotherapy to specify the severity of changes in the mucosa in oral mucositis in relation to the level of severity of leucopenia:

0 . Correct status, with no signs of mucositis - WBC $>3.9 \times 109 /$. 1. Benign changes in the mucosa (occurring focally): pale mucosa with redness point, no sensitivity, normal eating - WBC $3.0-3.9 \times 10^{9} / 1$.

2. Benign changes in the mucosa (occurring focally): redness (thickness reduction) of the mucosa, small erosions $<2 \mathrm{~mm}$, low sensitivity, normal eating - WBC $2.0-2.9 \times$ $109 /$.

3. Moderate changes in the mucosa (occurring over a larger area): redness (erosions), half the area of the mucosa occupied, bloody petechiae, but not bleeding spontaneously, moderate sensitivity to external stimuli, difficulty eating - WBC $1.0-1.9 \times 10 \% /$.

4. Advanced mucosal changes (generalized): redness (erosions), more than half the area of the mucosa occupied, bloody petechiae, bleeding spontaneously, pain, inability to eat and drink $-W B C<1.0 \times 109 /$ [ [15]. 
According to the classification of CTC ECOG (Eastern Cooperative Oncology Group Common Toxicity Criteria Scale), which is used to evaluate the toxicity of chemotherapy in oncology, the severity of mucositis is defined in the following scale:

0 - no change,

1 - painless ulcerations, erythema or mild soreness,

2 - erythema accompanied by soreness, oedema or ulcerations, taking solid foods is possible,

3 - erythema accompanied by soreness, oedema or ulcerations, taking solid foods is not possible, a liquid diet,

4 - the need for parenteral nutrition [16].

For patients undergoing radiation therapy the scale of the NCl-CTC (National Cancer Institute Common Toxicity Criteria Scale) is used, in which:

0 - means no change,

1 - redness of the mucous membrane,

2 - changes covered by pseudomembranes with a diameter less than $1.5 \mathrm{~cm}$, not confluent,

3 -confluent lesions larger than $1.5 \mathrm{~cm}$,

4 - deep ulcerations, with the possibility of bleeding and tissue necrosis [17].

The RTOG/EORTC (Radiation Therapy Oncology Group/European Organization for Research and Treatment of Cancer) classification includes only complications of radiation and takes into account the time of their occurrence (early and late complications).

In cases of association of chemotherapy with radiation the negative effects of both types of therapy are additive. The classifications presented above do not allow the assessment of side effects of combination therapy. Likewise, they do not allow one to obtain uniform results of changes occurring in patients treated with different therapeutic methods. Considering all these problems a new classification has been developed, CTCAEv3.0 (Common Terminology Criteria Adverse Events version 3.0), which has been widely used since 2003. This classification does not include the time of adverse effects of therapy. The effects have been grouped into eight categories. The basis of award categories are the anatomical and pathophysiological criteria. The therapeutic procedure in relation to various adverse reactions was determined regarding the degree of their severity $[14,18]$.

\section{Professional dental care}

Precise clinical examination and pantomogram allow planning of oral rehabilitation. Dental treatment is necessary to eliminate all sources of possible injuries and infections. Preparation of the oral cavity and dental extractions should be initiated early enough and not later than 7 days before chemotherapy and 14 days before radiotherapy, due to the fact that it takes time for healing of wounds after surgery. All surgical procedures should be done with full antibiotic cover and after the control blood cell count $[19,20]$.

In the course of chemo- or radiotherapy surgical procedures are contraindicated because of associated haematological disorder, risk of infection, healing complications, and the possibility of demonstration of symptoms of osteoradionecrosis!

Planned dental procedures should be limited solely to the prevention of dental caries for a patient undergoing chemotherapy treatment.
In patients undergoing chemotherapy it is permissible to perform the necessary surgical procedures 7 to 10 days before the next scheduled cycle of chemotherapy after prior consultation with the oncologist regarding the state of haematology (platelet and granulocyte levels).

There are no contraindications to conservative treatment of teeth and administration of local anaesthetics in these patients. However, due to their high susceptibility to infection in this period, associated with neutropenia, the treatment should strictly consider the principles of asepsis and antisepsis.

If possible, waiting with extractions for 12 months and carrying out the treatment with careful surgical wounds supply is recommended, preferably in a specialized centre, although there are reports that the likelihood of complications in the restrictive procedure is not high [7, 21]. Only in exceptional cases is extraction performed after radiotherapy at the earliest 3-6 weeks after irradiation, when the next course of radiotherapy starts at least after 3-4 weeks [11].

In patients with malignancies of the head and neck area, the removal of a tooth can cause spreading of cancer cells, because this treatment should be carried out for a day or two before the dose of radiotherapy. In cases when extraction of more teeth is necessary the procedure should be done carefully, including alveoloplasty, increasing the likelihood of proper healing and prosthetic rehabilitation after radiotherapy. Implementation of the new dentures is recommended at the earliest 6 months after completion of radiotherapy [7].

Conservative treatment of teeth. Reconstruction of decayed and damaged crowns and replacement of amalgam fillings is necessary, as well as smoothing sharp edges of crowns of the teeth. Exogenous fluoride prophylaxis by means of varnishes and gels, which can penetrate the enamel up to 1920-1950 nm, should be applied once a day $[3,11]$.

Periodontal treatment. The cure of gum inflammation and periodontitis, scaling and root planing and oral hygiene instructions must precede the basic treatment of cancer.

Surgery treatment. Eligible for extraction are necrotic tooth roots, teeth with deep caries not suitable for conservative treatment or those of doubtful prognosis, with advanced periodontitis (greater than $5 \mathrm{~mm}$ deficit of the alveolar process), teeth with periapical lesions (granulomas, cysts) and partially retained third molars at risk of pericoronitis. In the case of radiation on the irradiated side there should only remain live teeth with no signs of mobility, and in the case of the residual dentition only the teeth which are not in contact with the mucous membrane of the alveolar process of the opposite side so as not to cause additional irritation [7].

Orthodontic treatment. Before the commencement of oncological treatment fixed braces should be removed to avoid the risk of injuring the mucosa.

Prosthetic treatment. Leaking permanent dentures should be removed and removable dentures should be checked, especially if ill-fitting ones would predispose to the emergence of prosthetic stomatitis. It is essential to remove the prosthesis at night or if possible not use them 
for the period of therapy. Dentures must be washed daily and soaked in disinfectant solutions to prevent superinfection of Candida albicans [3]. All metal appliances must be removed before radiotherapy: crowns, inlays, amalgams. If the area of irradiation includes masseter muscles, it is necessary to mechano-active and sustain normal function of these muscles, for example making exercises of opening and closing the mouth, preferably by applying a slight resistance by using a two-hand grip of the mandible several times during the day. In the absence of opposing teeth prevention of localized alveolar act of biting on the opposite side is recommended by means of an overlay of thermoplastic material, which can also function as fluoride gel applicators [7]. In some cases, during the course of radiotherapy-caused xerostomia it is recommend to use acrylic overlay crowns or bridges on the permanent teeth [11]. It is recommended to eliminate harmful habits and parafunctions without contact of teeth.

\section{Recommendations for prophylaxis and therapy}

After each meal and before bedtime the patient should brush his teeth with a soft brush (which should be changed every month) using a toothpaste containing aminofluorides (Elgydium Protection caries) or pastes for children with low content of sodium lauryl sulfate, which can irritate the mucous membranes. After brushing, to wash out the mouth, and also during the day, saline solution or liquid mouthwash can be used. Flossing should be done once a day, preferably by means of a waxed dental floss [3]. It is also recommended to stimulate saliva flow by chewing sugarfree gum with no flavourings (V6-Stimorol, Freedent-Wrigley). Saliva substitutes (so-called artificial saliva) reduce the feeling of dryness, and at the same time, thanks to the content of additional substances, such as are present in natural salivary secretion, supplement its deficit (Viva-dental, Salivarex, Si-dent). Also used are medicinal properties of herbal infusions and extracts, such as chamomile, linseed, and mallow leaves [3, 15].

Application of glucocorticoids with regard to their antiinflammatory effect, involving the cessation of production of inflammatory mediators at the cellular level, is possible. However, the necessity of prescribing them is not unambiguously confirmed [11, 22]. In the treatment of druginduced mucositis accompanying chemotherapy, benzydamine hydrochloride is a highly valued drug, which is antibacterial and locally anaesthetic. Lining with an aqueous solution of vitamin A affects the mucosa positively. Both local and general application of vitamin A has anti-inflammatory properties, accelerates healing, stimulates the epithelium to faster multiplication, and reduces the severity of the lesions, as well as vitamin E, which is antioxidant and reduces the duration of mucositis [22, 23]. In the control of bacterial plaque a cautious approach to the use of chlorhexidine is recommended. Chlorhexidine is known for its excellent antibacterial and antifungal activity. However, in atrophic inflammation the rinse might be poorly tolerated due to the possibility of exfoliation of the epithelium [11]. In addition, chlorhexidine co-present with the local immune deficit may affect the microorganisms in a way that would destroy the ecosystem of the oral cavity and delay healing of mucosal lesions.

Rinsing with alcohol or hydrogen peroxide can irritate the mucosa and aggravate dryness [3]. In cases after irradiation or cytostatic medicine atrophic mucositis, do not use an ointment based on salicylates (Sachol) or containing papain and antibiotic (Carident, Peridontone) and caustic drugs [11]. Ulcerations are covered with 0.5-1\% aqueous aniline dye, xylocaine gel, and adhesive ointment (Orabase, Solcoseryl dental). In the case of superinfection by Candida species it is recommended to use gel, soothing pain and irritation of mucous membranes (Parodium). It is indicated to use nutritional cream on red lip, and avoid the use of protective lipstick containing Vaseline and petroleum due to its drainage properties [3].

\section{Medications generally recommended}

To prevent fungal infection (candidiasis) fluconazole is prophylactically administered (100 mg daily). Nystatin suspension should be avoided due to the high sugar content and unpleasant taste, which can also induce vomiting [3]. Pimafucin, natamycin and ketoconazole also have antifungal activity [24]. In cases of viral infections, such as the herpes virus group, or (far fewer) varicella zoster virus (VZV), Cytomegalovirus (CMV), Epstein-Barr virus (EBV) and HHV-6, 7,8 , it is necessary to give general formulations of acyclovir $[3,15]$. If a bacterial infection occurs it may be necessary to administer semi-synthetic penicillin antibiotics, clindamycin or clarithromycin.

\section{Diet}

Changing nutritional habits should lead to restriction of carbohydrates. Consumption of simple sugars should be replaced by food products containing aspartame, acesulfame, sorbitol or xylitol [3]. The patients should avoid too hot, cold, salty, sweet, spicy and acidic food. It is necessary to reduce consumption of juices, coffee and tea, and of thirstincreasing or dry biscuits, crackers and crisps. In the course of therapy drinking and smoking are strictly forbidden.

\section{Summary}

Patient care and treatment of cancer is a particularly difficult process, requiring the cooperation and involvement of physicians of different specialties. Children prepared for oncological treatment should be given priority. Undoubtedly very important for the development of lesions in the oral cavity associated with chemotherapy is the state of the patient's mouth at the beginning of the treatment and his ability to maintain proper oral hygiene. The role of the dentist before chemotherapy is to remove all dental related factors predisposing to inflammation during treatment, learning how to control the patient's oral hygiene and treatment of pathological lesions occurring in the oral cavity during chemotherapy. Alleviating effects of implemented treatment may become one of the factors enabling the total eradication of a cancer disease. Learning proper habits also requires a large commitment of the patient in maintaining a hygienic regime at that particular time of his life. 


\section{References}

1. Hamerlak Z, Banach J. Wyniki leczenia ciężkich zapaleń jamy ustnej u dzieci chorych na ostre białaczki i chłoniaki złośliwe. Dent Med Probl 2004; 41: 687-94.

2. Karolewska E, Konopka T, Pupek M, Chaber R. Mucositis in children with leukemia and salivary defense factors. Dent Med Probl 2007; 44: 30-6.

3. Pawlik A. Powikłania chemio- i radioterapii w obrębie jamy ustnej. Twój Przegląd Stom 2008; 6: 66-70.

4. Karolewska E, Kozłowski Z, Konopka T, Mendak M. Zmiany na błonie śluzowej jamy ustnej w przebiegu białaczek u dzieci - obraz kliniczny. Dent Med Probl 2004; 41: 675-81.

5. Kiernicka M, Owczarek B, Podsiadła-Urban G, Wysokińska-Miszczuk J. Powikłania w jamie ustnej po chemioterapii w leczeniu nowotworu - opis przypadku. As Stom 2008; 5: 6-9.

6. Dolegacz-Bączkowska A, Bączkowski B, Rolski D. Występowanie zmian w jamie ustnej pacjentów po radioterapii. Nowa Stomatol 2004; 30: 185-8.

7. Sidorowicz K, Sokalski J. Ambulatoryjne postępowanie stomatologiczne u pacjentów leczonych chemio- i radioterapią. Dental Forum 2007; 35: 77-80.

8. Olczak-Kowalczyk D, Perek D, Daszkiewicz M, et al. Problemy stomatologiczne u dzieci z chorobami nowotworowymi. Doświadczenia własne. Nowa Stomatol 2003; 26: 175-9.

9. Paulino AC, Simon JH, Zhen W, Wen BC. Long-term effects in children treated with radiotherapy for head and neck rhabdomyosarcoma. Int J Radiat Oncol Biol Phys 2000; 48: 1489-95.

10. Syryńska M, Janiszewska-Olszowska J, Bielawska H. Obraz kliniczny i radiologiczny odległych powikłań stomatologicznych leczenia nowotworów złośliwych wieku dziecięcego w obrębie głowy. Onkol Pol 2007; 10: 30-6.

11. Rump Z. Wpływ chemio- i radioterapii przeciwnowotworowej na tkanki jamy ustnej. Zintegrowane postępowanie lecznicze. Stomatol Współcz 2006; 13: 37-41.

12. Darczuk D. Zmiany w jamie ustnej wywołane napromienianiem nowotworów głowy i szyi. Stomatol Współcz 1999; 6: 23-5.

13. Cioch M. Uszkodzenie bariery śluzówkowej (mucosal barier injury - MBI) w następstwie intensywnego leczenia cytostatycznego. Onkol Pol 2001; 4: 85-9.

14. Olczak-Kowalczyk D, Daszkiewicz M, Daszkiewicz P, et al. Wybrane problemy stomatologiczne pacjentów poddanych terapii przeciwnowotworowej na podstawie klasyfikacji CTCAE v3.0. Część I. Stomatol Współcz 2007; supl. 1: 20-7.

15. Drabarczyk-Nasińska M. Zapobieganie zmianom w jamie ustnej towarzyszącym chemioterapii nowotworowej i ich leczenie. Mag Stomatol 2004; 2: 18-20.

16. Oken MM, Creech RH, Tormey DC, Horton J, Davis TE, McFadden ET, Carbone PP. Toxicity And Response Criteria Of The Eastern Cooperative Oncology Group. Am J Clin Oncol 1982; 5: 649-55.

17. Samulak-Zielińska R, Trąbska-Świstelnicka M, Dembowska E. Oral mucositis w przebiegu radioterapii raka trójkąta zatrzonowcowego. Mag Stomatol 2010; 9: 98-103.

18. Olczak-Kowalczyk D, Daszkiewicz M, Kowalczyk W, et al. Wybrane problemy stomatologiczne pacjentów poddanych terapii przeciwnowotworowej na podstawie klasyfikacji CTCAE v3.0. Część II. Stomatol Współcz 2007; 3: 30-7.

19. Kanatas AN, Rogers SN, Martin MV. A survey of antibiotic prescribing by maxillofacial consultants for dental extractions following radiotherapy to the oral cavity. Br Dent J 2002; 192: 157-60.

20. Lewandowski L. Onkologia szczękowo-twarzowa. Wybrane zagadnienia kliniczne. AM Poznań, Poznań 2004; 24-25: 155-60.

21. Chang DT, Sandow PR, Morris CG, et al. Do pre-irradiation dental extractions reduce the risk of osteoradionecrosis of the mandible? Head Neck 2007; 29: 528-36.

22. Pleova P. Prevention and treatment of chemotherapy - and radiotherapy - induced oral mucositis: A review. Oral Oncol 1999; 35: 453-70.

23. Herrstedt J. Prevention and management of mucositis in patients with cancer. Int J Antimicrob Agents 2000; 16: 161-3.

24. Łukaszuk C, Krajewska-Kułak E, Wojtukiewicz M, et al. Zakażenia grzybami drożdżopodobnymi u chorych na nowotwory. Onkol Pol 2002; 5: 25-34

\section{Address for correspondence}

\section{Marta Puławska}

The Department of Oral Surgery

Medical University of Lublin

Karmelicka 7

20-081 Lublin 